on numerous committees. In its analysis of the results of the examination of 848 samples of imported butter, the report shows that the water content of considerably more than half of the samples was between 15 and 16 per cent; the Reichert value of the fat varied from $24 \cdot 0$ to $34 \cdot 0$ (in 555 cases from 28 to 32 ), while the Polenské value varied from $1 \cdot 0$ to $3 \cdot 35$. Of 87 samples of tinned cream, 81 contained between 20 and 29 per cent of fat ; of 127 samples of cheese, 17 per cent had been prepared from milk containing less than one half of its fat. In neither case is it at present possible to take exception to such im. portations. The examination of water included sea water studies for the use of hydrographers and biologists, on rivers in connexion with fish and fish food, and on water-cress beds in relation to the use of the national mark. Of 2,270 samples of brewing materials, 18 contained arsenic in slight excess of the accepted limit. It is satisfactory to learn that owing to the stringency of the tobacco laws and the high standard of the tobacco industry in Great Britain, adulteration is almost non-existent. The Laboratory has also been concerned with such widely different matters as the pollution of foreshores, the manipulation of radioactive materials, the carriage of dangerous cargo, and the work of the Bed-bug Infestation Committee.

\section{Carrier Telephony}

AN instructive address on carrier telephony was delivered to the London Students Section of the Institution of Electrical Engineers, on October 31, by its chairman, P. H. Pettifor. The frequencies present in the normal speech range are included between the limits 75-9000 cycles per sec., but for intelligible and 'natural' speech, it is only necessary for the listener to hear a very small portion of that spectrum, and in normal telephone practice the range lying between 300 to 2700 cycles per second only is used. This possible restriction in the range necessary for satisfactory speech is fully utilized in carrier telephony. The lower the frequency of the transmitted band the greater the number of channels which can be accommodated for that band. A carrier-current telephone system is one in which the normal vaice frequencies are raised to a band of higher frequencies before being transmitted over the open-wire line or cable, conversion to the normal voice frequency band taking place at the receiving station. If different circuits have their voice frequencies raised by amounts such that the high-frequency bands do not overlap one another, then one cable pair can be used to transmit speech to several circuits, without the circuits interfering with one another. In this way the signals in several circuits can be transmitted over one cable pair without any interference taking place. The development of the principles of carrier telephony has been slow; the early experiments were made by Ruhmer in 1909 , before the present-day thermionic devices were developed. A brief description was given of the postWar development in this field, including the latest cable design technique. Amongst the types of cable described was a cable containing a pair of air-spaced self-locating conductors. This type of cable is laid around London for television purposes. Another type containing four coaxial conductors has been laid between London and Birmingham. A similar coaxial cable containing only one coaxial conductor insulated with para-gutta has also been found very useful. With modern systems the level of cross talk between channels is practically negligible when compared with the normal voice frequency systems.

\section{A 'New Deal' in Education}

President Roosevert's Advisory Committee on Education, appointed in September 1936, has presented a report (Government Printing Office, Washington, 1938. Pp. 244. 35 cents) on the whole subject of Federal relationship to State and local conduct of education. After a comprehensive study of the entire field of educational service, the committee found that there is great need for improvement of the public schools in a number of broad geographical regions and in the rural areas generally. To redress the existing gross inequalities of educational opportunity it submits a set of carefully articulated proposals forming, as is justly claimed, "a unified and coherent pattern of Federal policy" and involving a six years plan for Federal grants for educational services amounting in the aggregate to 1,200 million dollars. Most of the new grants recommended fall under the headings : general aid to elementary and secondary education, preparation of teachers and other educational personnel, school buildings, administration of State departments of education, educational services for adults, library service for rural areas. A system of co-operative research accompanied by demonstration projects throughout the country has proved its value in the field of agriculture, and the committee recommends the establishment of a special Federal fund for the immediate application of such a system in the field of education. In the first instance it would be utilized especially for elucidating in advance problems bound to arise in connexion with the operation of the six years plan for Federal grants.

\section{The Colombo Museum}

THE administration report for 1937 of the acting director of the Colombo Museum, P. E. P. Deraniyagala, shows that in many directions the activity of the museum is maintained. Steady additions are being made to the zoological collections, notably by expeditions carried out by the staff or by the staff jointly with representatives of the British Museum, so that the director considers that the accumulation of material is now sufficient to justify the publication of detailed monographs. At the same time, attention ought to be directed to the public galleries, and the replacement of the misleading and faded specimens in the bird gallery would doubtless be appreciated by the half-million visitors who pass through the galleries each year and especially by the large number of school-children $(12,288)$ who make use of the exhibits in the course of their nature study instruction. 
A suggestion that the collection of living animals should be transferred to the Government Zoological Gardens at Dehiwala was strenuously opposed by the Committee of Management, and instead efforts are being made to improve and extend this museum zoo, which is an invaluable educational adjunct to the mounted collections. The Ethnological Department has begun a survey of the native population, and various expeditions have been carried out for a study of cultural institutions and social and economic conditions.

\section{Trachoma in Tunisia}

IN a recent study (Thèse de Paris, 1938, No. 142), Dr. C. Koskas states that trachoma was probably imported into Tunisia by immigrants from North Africa, Italy, Malta and Spain. Although it is a notifiable disease, the natives, who do not recognize the gravity of the condition, evade the law, and comparatively few cases are actually notified. The only means of determining in any way the trequency of the disease is by medical examination of school children or of recruits for the army. There is no doubt, however, that infection rarely occurs in adults or in the schools; but that it is usually contracted in the early months of life. The incidence of the disease is much higher in the south where the climate is hot, the sirocco violent and frequent, the atmosphere laden with dust and sand, and the inhabitants poverty stricken and underfed than in the north of Tunisia. Flies play an important part in the transmission of the disease, as was shown by Nicolle and Cuenod in 1921, Petit in 1925 and Mme. Delanoe in 1930 ; but race does not influence the incidence or gravity of the disease. Good work has been done by the establishment of ophthalmic departments where free advice and treatment are given.

\section{Electrical and Allied Manufacturers' Association}

THE eleventh edition of a pamphlet giving information about the British Electrical and Allied Manufacturers' Association (BEAMA) has just been published. The president of the Association is the Earl of Derby. The objects of the Association are to foster and protect the electrical and allied industries in Great Britain. It aims at securing the co-operation of every firm in the electrical and allied industries so that, by co-operative action, it can speak for the whole of those industries on all matters affecting them. The Standardization Committee acts as a centre and clearing house for the many activities of its members in connexion with standardization and the British Standards Institution. The Association's numerous technical and other committees are continuously at work in the interests of the sections by which they are appointed and of the members generally. The address of the Association is 36 Kingsway, W.C.2.

\section{Earthquake in Bulgaria on November 6}

AT approximately $21 \mathrm{~h}$. G.C.T., an earthquake damaged property and felled chimneys in the Gabrovo district in north Bulgaria. Many people were alarmed, but no loss of life is reported. Bulgaria as a whole must be considered an earthquake country, though the north has not been subjected to so many as the south. The chief epicentral region in north Bulgaria is around Timovo, and the next in importance is the Déli-Orman. Further information concerning the shock will probably come shortly from Dr. K. T. Kiroff and his colleagues at the observatory at Sofia.

\section{Japanese Earthquake of November 5}

As earthquake was experienced in the Miyagi Prefecture in the north-east of the main island of Japan at $8 \mathrm{~h} .44 \mathrm{~m}$. G.C.T. (5.44 p.m. local time), and an after-shock followed two hours later. The focus appears to have been at some considerable depth, as the shock was felt in the four Prefectures of Miyagi, Iwate, Fukushima and Ibaragi, and even as far as Tokyo, though no damage is reported from this city. In this part of Japan there is a well-defined belt of earthquake epicentres stretching from Kamagata through Wakamatsu and Utsunomiya to Choshi. Severe earthquakes happened in the north end of this belt in 1893,1894 and 1895, the last two from the same epicentre, though more recently strong earthquakes have been more frequent along parallel belts to the south, west, north, and seaward of this. The shock which was recorded on seismographs at Kew and elsewhere in Great Britain at $8 \mathrm{~h} .55 \mathrm{~m} .59 \mathrm{~s}$. G.C.T. and mentioned in the general press in connexion with the above, was not due to the Japanese earthquake but was from some epicentre at about $87^{\circ}$ from $\mathrm{Kew}$, though the exact location is not yet determined.

\section{Commonwealth Fund Fellowships}

THE total number of Commonwealth Fund Fellowships offered for award in 1939 is thirty-four. These fellowships are tenable at certain American universities. Candidates for Ordinary Fellowships must be of British descent who are domiciled in the United Kingdom of Great Britain and Northern Ireland, and are degree graduates of recognized universities therein. Candidates for Dominion Fellowships must be of British descent from the British Dominions, who have studied, but not necessarily graduated, at a university in the United Kingdom of Great Britain and Northern Ireland, who are degree graduates of a recognized university in a British Dominion or Colony. Candidates for Service Fellowships must be of British descent and must hold appointments overseas under the British Government, or the Government of India, or the Government of a British Dominion, Colony, Protectorate or Mandated Territory; and those for Home Civil Service Fellowships must be holding appointments in the Home Civil Service. None of these fellowships is open to women. Further information can be obtained from the Secretary to the Committee, Commonwealth Fund Fellowships, 35 Portman Square, London, W.1.

\section{International Union of Geodesy and Geophysics}

THE International Union of Geodesy and Geophysics will hold its seventh general assembly in Washington, U.S.A., on September 4-15, 1939. 